Feature : Toward river restoration in East Asia-Pacific Region

REVIEW

\title{
New Zealand's resource management system and its effectiveness
}

\section{Keiko NAGASHIMA* and Nobukazu NAKAGOSHI}

Ecol. Civil Eng. 6(1), 73-85, 2003.

Graduate School for International Development and Cooperation, Hiroshima University, 1-5-1, Kagamiyama, Higashi-Hiroshima, 739-8529, Japan

\begin{abstract}
The importance of a resource and forest management system integrated with land use management is widely recognized in the world. New Zealand (NZ) was the country took the lead to establish the integrated resource management system by dividing the role of natural forests and plantation forests clearly and by establishing the Resource Management Act 1991 (RMA). This review aims to introduce NZ's forest management system, their developing processes and the effectiveness or problems of the system. Comparison to Japan's forest management system was also stated.

The dichotomous management system, which manages indigenous forest for environmental conservation and plantation forest for timber production, allowed the indigenous forests to be free from harvesting. New Zealand was able to conduct this system because of (1) the small area of indigenous forest remaining on the hill countries, (2) the development of plantation forestry to a promising industry and (3) the pressure of rationalization and the conservation movement. The dichotomous forest management system itself is not likely to apply for Japan because of the difference of forest distribution pattern and the profitability of forestry. Nonetheless, the process for clarifying the role of administration bodies and the legislation related to forests might be able to introduce because forest legislations and their administration bodies are still fragmented in Japan.

The establishment of the RMA accompanied by the central government reform, local government reform, and the integration of environmental legislations. These processes enabled the RMA to provide the platform to implement integrated resource management. Although some problems are still remaining, the RMA is an advanced comprehensive environmental law that put every effort to minimize contradiction among legislations and conflicts among the administration bodies. In order to establish an integrated resource or forest management system in Japan, reviewing processes of the administration system and legislations as conducted in NZ might be important.
\end{abstract}

Key words: administrative and economic reform, dichotomous forest management, environmental impact assessment, integrated resource management, Resource Management Act

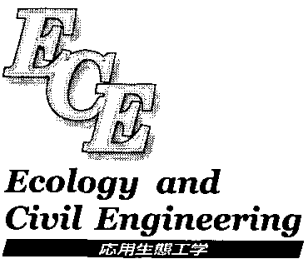

Received 26 September 2002; Accepted 16 June 2003

* e-mail: junior-h@wd6.so-net.ne.jp

Present address: River Bureau, Ministry of Land, Infrastructure and Transport, 2-1-3, Kasumigaseki, Chiyoda-ku, Tokyo 1008918, Japan 


\section{Introduction}

Expanding human requirements and economic activities are placing ever increasing pressures on land resources, creating competition and conflicts and resulting in sub-optimal use of both land and land resources (UN 1992). Forests worldwide have been and are being threatened by uncontrolled degradation and conversion to other types of land uses. The loss and degradation of forests result in soil erosion, loss of biodiversity, damage to wildlife habitats and degradation of watershed areas. Those impacts will cause deterioration of the life quality and reduction of the options for development. The present situation calls for urgent and consistent action for conserving and sustaining forest resources. In order to minimize conflicts, to make the most efficient trade-offs and to link social and economic development with environmental protection and enhancement, integrated approach must be adapted to forest management. The Agenda 21 mentions the necessity of a national forest management plans for conservation and sustainable development of forests, which should be integrated with other land uses (FAO 1996). In other words, it emphasized the importance of managing forests as a part of land-use management by establishing an integrated resource management system (UN 1992).

A number of countries have elaborated national policies and procedures for integrated resource management and have introduced changing in land administration (UN 2001). Initially some plans focused on delineating areas for protection as nature reserves, critical watersheds and other environmentally important areas. Gradually the scope has expanded to encompass sustainable land-use or land resource plans in a wider geographical and a longerterm perspective. For example, the United States has started to implement the integrated resource management system so called "ecosystem management." Germany makes an effort to connect significant natural ecosystem throughout the country (Kakizawa 2000). However, in many countries, policies for integrated resource management remain fragmented and incomplete, generally because of institutional barriers, conflicting mandates, and the prioritization of economic over social and environmental goals and of short-term development over long-term conservation goals (UN 2000). Considering Japan's situation, it might be included in one of those countries.

On the other hand, New Zealand (NZ) was the country took the lead to establish the system of integrated resource management. In the late 1980s, NZ had decided to divide the role of natural forests and plantation forests clearly. The former was managed for environment and biodiversity conservation, and the latter for timber production. New Zealand also established the Resource Management Act (RMA), the first statute including all laws related to the use of land, air and water, in 1991. Legislations were integrated and the enactment of the RMA culminated in the repeal of a number of major pieces of legislation. Legislations related to forest management apply alongside any controls imposed under the RMA, which means that both forestry activity in plantation forests and management strategy of indigenous forests should not contradict to the RMA. NZ's resource and forest management system is the leading integrated system that put every effort to minimize contradiction among legislations and conflicts among the administration bodies.

This review aims to introduce NZ's forest and resource management system and their developing processes and to discuss the effectiveness or problems of the management system. Comparison of NZ's resource management system with Japan's forest management system is discussed at the end of the review.

\section{Dichotomous forest management}

The decision to manage NZ's forest dichotomously (manage natural forests for environmental conservation and plantation forests for timber production) is a result of NZ's socio-economic background. The first background is that only a little indigenous forest (23\% of the national land area) was remained on the steep slopes because indigenous forests on gentle slopes had been deforested and converted to pasture. The second important background is that the plantation forestry had already grown up as a promising industry for exportation by the late 1980s. Since the late 1960s, when a great concern on the dramatic decrease and degradation of NZ's indigenous forest was occurred, plantation forestry expanded remarkably from 352,000 ha in 1960 to 1,095,000 ha in 1985 (New Zealand Ministry of Agriculture and Forestry 1998). The last back- 
ground is the pressure of forest management rationalization and the conservation movement. In the late 1980 s, NZ experienced stagnation and it resulted in the call for an economic reform that easing restriction, abolishing subsidies, privatizing state-owned corporation, and selling stateowned properties (Konohira 1989). The Forest Service, which had responsibility both for plantation and indigenous forest management, was taking the multiple-use approach by then. However, the Ministry of Finance criticized the inefficiency of the work of Forest Service and the multiple-use approach was pointed out as the cause of its inefficiency (Bilek 1994). Therefore, rationalization of the forest management system was required. In addition, environmental conservation groups indicated the confliction of interest of the multiple-use approach. They concerned the result of indigenous forest management, which was managed by departments with major interests in commercial forestry and land development (Kirkland and Berg 1997).

Under the pressures of rationalization and conservation movement, the New Zealand Forest Service was disbanded in 1987 in favor of Department of Conservation, a Ministry of Forestry and the New Zealand Forestry Corporation (Minowa 1997a) (Fig. 1). The management purpose of each organization was simplified. The economic activity and non-economic activity of the Forest Services were divided clearly into different agencies. The Department of
Conservation was for native forest management which goals are to protect and preserve biological, aesthetic and other natural attributes under the Conservation Act 1987. The Ministry of Forestry took the policy and regulatory role, and the Corporation was for commercial plantation forestry. Later, the state's commercial forest was sold and the corporation was privatized.

The dichotomous forest management itself became one of the causes for the current prosperity of plantation forestry in NZ. The rate of afforestation increased remarkably from 1990, which is recognized as the third boom of afforestation. The area of plantation expanded from $1,261,000$ ha in 1990 to $1,799,000$ ha in 2001 (New Zealand Ministry of Agriculture and Forestry 2002). It is still the midst of the third boom and the expanding rate is about 40,000 ha to 60,000 ha per year.

\section{Effectiveness of the dichotomous forest management}

The effectiveness of the dichotomous forest management is strongly related to the impact of plantation forestry to the environment since it was the dichotomous forest management that enhanced the remarkable expansion of plantations in the 1990s (the third boom). The expansion of plantation forests in New Zealand has greatly modified the

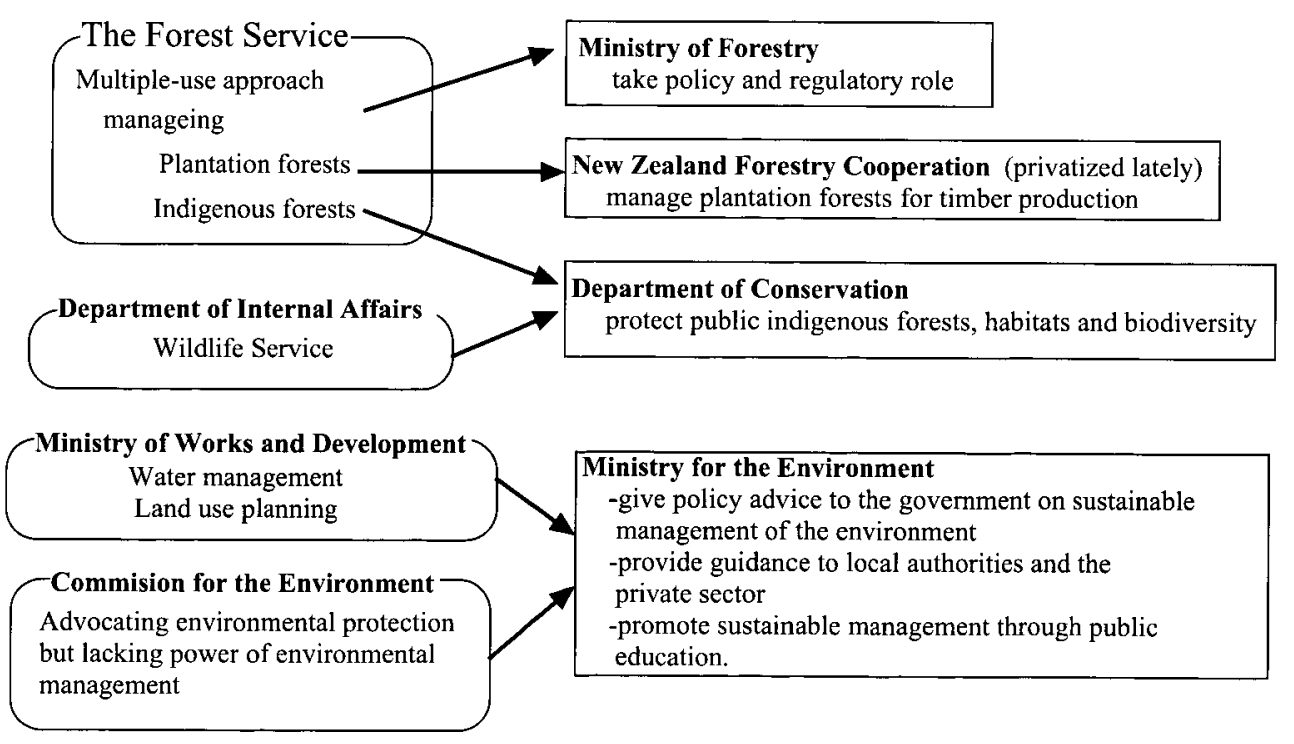

Fig. 1. Outline of central government reform related to the establishment of integrated resource and forest management system. 
landscape. In the ten years from 1985 to 1995, the planta tion estate increased by 35\% (New Zealand Ministry of Agriculture and Forestry 1998). During this period 1.9 million ha of pastures for grazing sheep and cows were converted to other land uses, especially to plantations (Masui 1996). Based on statistical data, several other studies also reported that plantations have been established on pastures in recent times (e. g. Fletcher 1984; Le Heron \& Roche 1985; Taylor et al. 1997). Because plantation is expanding by converting pasture and not the indigenous forests, it is said that it has lesser impacts on the natural environment. Sutton (1995) argued that New Zealand's plantations allow the indigenous forests to remain free of wood harvest and so let it to be protected. Although it is generally considered that the biodiversity in plantations is poor, various studies indicate that it is richer in native species biodiversity than previously considered (Allen et al. 1995b; Spellerberg \& Sawyer 1995; Dycke 1997). Many studies reported that plantations have quite high plant species richness in their under-storeys (e. g. Allen et al. 1995a; Ogden et al. 1997) and have an ability to maintain native birds (e. g. Gibb 1961; Clout 1980; Clout \& Gaze 1984). Reduction of soil erosion due to the replacement of pasture by plantation is also observed (Hick 1991; Marden \& Rowam 1993; MacLaren 1996). Hence, the dichotomous forest management and the following plantation expansion are likely to contribute to protect indigenous forests and improve the environmental quality.

However, a study examined the landscape dynamics by map overlays indicated the influence of plantation forestry on shrub lands. Investigating the land use change pattern from 1970 to 1996 in the Nelson region, little changes in the net area of indigenous forest was observed as like the studies based on the statistical data (Nagashima et al. 2002). However, more shrubs than pasture was converted to plantation over the period. It was also the first land use type converted to other land use (Table 1). The reason for remarkable development of shrub might be because lesser conservation priority was put on shrub than indigenous forest. Nonetheless, shrub is important not only as an area regenerate to indigenous forest (Bergin \& Kimberley 1995) but also because it has high biodiversity (Mark et al 1989; Dichinson et al. 1998). Although it was expected conversion of shrub to plantation reduced in the 1990s because of the Forest Accord 1992 that agreed not to replace regenerating shrub with plantation, Nagashima et al. (2002) pointed out the importance of monitoring the dynamics of shrub in the future.

\section{Establishment of the Resource Management Act}

Environmental laws in NZ, traditionally, had been regulated addressing specific environmental and resource management problems in relative isolation. For instance, land use and water control and management were dealt with in separate legislation with different objectives. Consent and enforcement functions were also exercised by quite separate administrative bodies (New Zealand Ministry for the Environment 1991). For instance, the Forest Service had a responsibility on indigenous forest management as mentioned in the previous section, the Department of Internal Affairs was responsible on wildlife services and Ministry of Works and Development took the role of land use planning and water management. The Commission for the Environment had the role of advocating environmental protection (Taylor et al. 1997) (Fig. 1). Increase awareness and understanding of environmental problems, however, have led people to recognize that the inter-connection between various elements of the environment necessitates an inte-

Table 1. Main land-use changes in the Nelson region between 1970 and 1996.

\begin{tabular}{lrrrr}
\hline Land use in 1970 & \multicolumn{4}{c}{ Land-use in 1996 (ha) } \\
\cline { 2 - 5 } & Pasture & Plantation & Indigenous forest & Shrub \\
\hline Pasture & 104,001 & 16,338 & 5,438 & 9,876 \\
Plantation & 2,416 & 45,501 & 1,773 & 1,292 \\
Indigenous forest & 5,965 & 4,553 & 486,552 & 21,368 \\
Shrub & 34,634 & 37,629 & 24,471 & 53,755 \\
\hline
\end{tabular}

Source: Nagashima et al. (2002). 
grated approach to environmental protection and resource development (Williams 1997). In order to reflect the complexity and inter-relatedness of the various elements of the biosphere, challenges to integrate legislation, administrative responsibilities and operational management were started as a part of the social and economic reforms in the late 1980s, before the establishment of Agenda 21 .

The Ministry for the Environment was established in 1986 as an administrative body for integrated resource management, which was accompanied by the dissolution of the Commission for the Environment. One of the key aspects of this change was the transformation of the statutory responsibilities for water management and land use planning to the Ministry for the Environment from the later dissolved Ministry of Works and Development (Tayler et al. 1997; Kakizawa \& Nozaki 2001) (Fig. 1). Ministry of Works and Development had a great voice on resource management but its interest was mainly on development. The transformation enabled the Ministry for the Environment to implement integrated resource management, which manage land-uses in conjunction with management of natural resource.

Reforms of environmental legislation were made in close association with local government reforms because the Ministry for the Environment recommended the local authorities to be the main players in the system of integrated resource management (Kakizawa \& Nozaki 2001). The Local Government Act was amended in 1989 to decentralize the power of land use and resource management, and to establish an adequate system that promotes sustainable resource management. The remarkable point of the innovation is that the geographical boundaries of the regions were decided based on natural river catchments in order to accelerate efficient resource management (Taylor et al. 1997; Kakizawa \& Nozaki 2001). Under the new arrangement, 13 regional councils and 74 territorial authorities were created. Regional councils are elected local government bodies that coordinate and set policy for resource management including water and soil conservation. Territorial authorities are elected district or city councils. The functions of territorial authorities are complementary to those undertaken by regional councils, but it focused on local service requirements (Taylor et al. 1997).

At the outset of creating an integrated resource manage- ment law, the government began a review of a number of statutes dealing with town and country planning, water rights and regulation, clean air control, mining licenses, noise control, and geothermal energy utilization in July 1988. Following extensive consultation activities with public bodies, interest groups and individuals throughout the country, the government issued a report that proposed to establish a single integrated resource management in December 1988 (Williams 1997). A year later, the Resource Management Bill was introduced into the Parliament.

Although the Labor Government was replaced by the National Government in 1990, the movement of legislation reform was retained due to the strong support from the public. Eventually, the RMA, the first integrated resource management law that includes the law relating to the use of land, air and water, was approved in 1991. The enactment of the RMA culminated in the amendment of 50 stat. utes and the repeal of a number of major pieces of legislation (New Zealand Ministry for the Environment 1991; Milne 1992; Hiramatu 1997; Williams 1997). As for forest management legislation, the Town and Country Planning Law which took partly of the role of nature conservation was repealed because it was found ineffective as a mechanism to protect natural environment (Hallett 1991). The Soil Conservation and Rivers Control Act that had responsibility for controlling flooding, soil and riverbank erosion was amended (New Zealand Ministry for the Environment 1991) (Table 2). Provision to preserve the natural character of lakes, rivers and wetlands, and protect the habitat of trout and salmon when taking measures to minimize and prevent flood erosion, was inserted in the Act (Milne 1992). A new control to manage the private indigenous forests in a sustainable manner was also established in the Forest Amendment Act (Williams 1997).

\section{Contents of the Resource Management Act}

The RMA is administered by the Ministry for the Environment and its purpose is "to promote the sustainable management of natural and physical resources." The key feature of the RMA is its focus placed upon the effects of the activities rather than upon the activities themselves (Milne 1992). This indicates the legal requirement of Environmental Impact Assessment (EIA). In other words, 
Table 2. Changes in forest management legislations accompanying by the establishment of the RMA.

\begin{tabular}{lll}
\hline Name of legisiation & Role of the legislation on forest management & Changed part \\
\hline $\begin{array}{l}\text { Town and Country } \\
\text { Planning Law }\end{array}$ & $\begin{array}{l}\text { Nature conservation was one of the roles of } \\
\text { the law although the provision had its prior- } \\
\text { ity on land development. }\end{array}$ \\
\hline $\begin{array}{l}\text { Soil Conservation } \\
\text { and Rivers Control }\end{array}$ & $\begin{array}{l}\text { Responsible for controlling flooding, soil and } \\
\text { riverbank erosion and provide protection } \\
\text { measures to landowner and communities. }\end{array}$ & $\begin{array}{l}\text { Amended } \\
\text { Regional councils must recognise and provide for } \\
\text { the preservation of the natural character of lakes, } \\
\text { rivers and wetlands, and protection of the habitat } \\
\text { of trout and salmon when minimising and prevent- } \\
\text { ing flood and erosion. }\end{array}$ \\
\hline Forest Act & $\begin{array}{l}\text { Amended } \\
\text { ing indigenous forest. }\end{array}$ & $\begin{array}{l}\text { Established a new control to manage the private } \\
\text { indigenous forest in a way that maintains the abil- } \\
\text { ity of the forest growing on that land. It also pro- } \\
\text { hibited the export of indigenous timber. The Act } \\
\text { applies alongside any controls imposed under the } \\
\text { RMA. }\end{array}$ \\
\hline
\end{tabular}

the RMA is a legislation that tries to avoid, remedy, or mitigate any adverse effects of activities on the environment by the EIA (Dixon and Montz 1995; Hiramatsu 1997).

Comparing with the previous laws, the role of central government in the management of natural and physical resources had reduced, which implies a corresponding increase in the autonomy of regional councils to decide policy within their own regions. The principal powers retained by central government are the making of national policy statements that express the national goals and objectives, the call-in procedures for projects of national significance and the making of regulations prescribing environmental standards (Fig. 2).

The regional councils are primary responsible for the management of water, soil, geothermal resources, pollution control, natural hazard mitigation, regional inter-relationships, and lake, riverbed, and coastal marine area management. Regional council is required to make a regional policy statement and regional plans (Fig. 2). The regional policy statement provides an overview of the resource management issues of each region and integrates the regional and district management of natural and physical resources. Regional plans contain detailed provisions relating to issues identified in regional policy statements.

At a local level, district plans, which might directly affect the actual land use, are required to made by the dis- trict councils (Fig. 2). The district plans include control over land use management, subdivision, noise control, and hazard mitigation.

District plans contain rules that define what activities can occur in all or part of the area covered by the plan. Activities are classified into 5 categories: permitted, controlled, discretionary, non-complying, and prohibited activities. The key difference between these different levels of activity is the likelihood that an application for consent will be granted. Permitted activity is allowed by the plan and no consent is necessary. Controlled activity is expressly allowed by the plan but consent has to be applied for (which has to be granted but which may have conditions attached [New Zealand Ministry of Forestry 1995]). Discretionary activity is an activity specified in the plan and is not prohibited. A consent is required and the decision to grant it or not is based on the criteria specified in the plan. Non-complying activity is an activity contravenes the plan. Consent cannot be granted unless the consent authority recognized that the environmental effects will be minor or if the granting will not be contrary to the objectives and policies of the plan. Prohibited activity is not allowed and no consent can be sought. Activities that affect a wide range of people or have significant environmental effects should be publicly notified and a hearing will be held. Major effect on the environment by the activity will need to be 


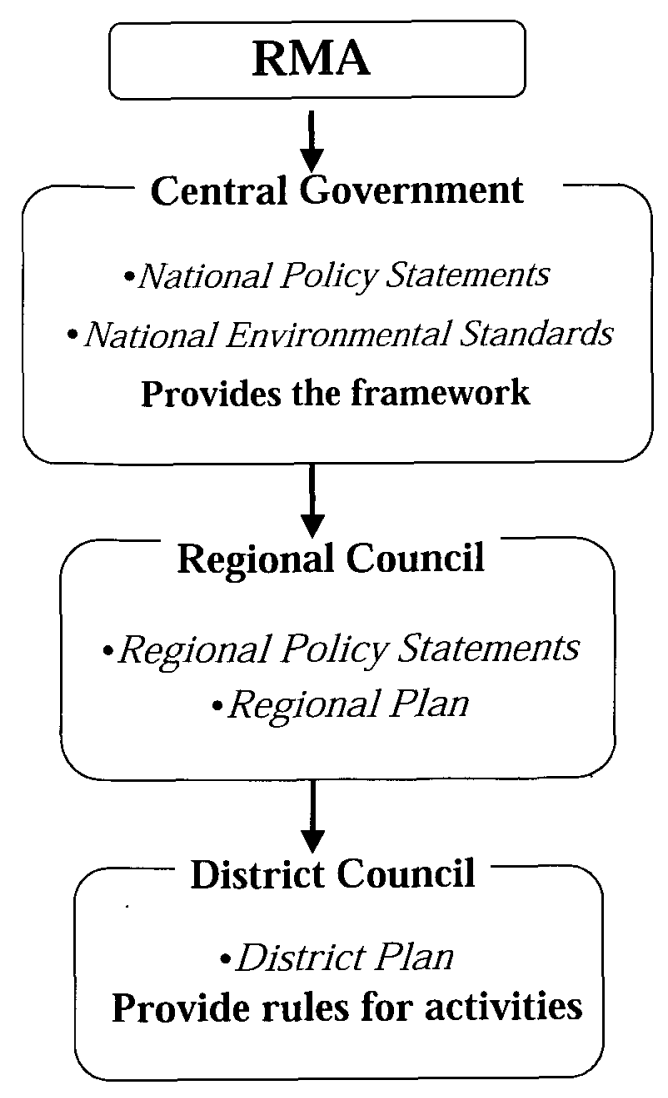

Fig. 2. Roles of the central government and the regional and district councils under the RMA.

supported by a detailed EIA and every consent application must be accompanied by an EIA (Fig. 3).

As each district council has its own district plan, forestry activities might be regulated differently between councils. Some local authorities might treat plantation establishment as a permitted activity but others might treat it as a discretionary activity that needs consent. For instance, the Tasman District and Nelson city recognize forestry activity as a permitted activity if the area distributes within the Rural zone (Nelson City Council 1999; Tasman District Council 2000). On the other hand, the district plan of Queenstown Lake District council declares that forestry activity in the Rural General Zone is a discretionary activity if the planted species is one of those listed in the plan. Forestry activity of any other species is permitted if it undertakes a boundary of $20 \mathrm{~m}$ from a neighboring property and if it is not undertaken in alpine areas with an altitude greater than $1070 \mathrm{~m}$ above sea level (Queenstown Lake District Council 2002).
Because most of the indigenous forests in NZ are designated as a Conservation area and because the RMA declares the importance of protections of significant indigenous vegetation and significant habitats of indigenous fauna, removal of indigenous forests are basically prohibited. However, removal of indigenous vegetation without the conservation estate might happen if the consent was granted. The criteria for deciding to grant the consent or not might be also different between councils. Clearance of indigenous forest in Rural zone of the Tasman District and Nelson City is only permitted if the total cleared area does not exceed 0.2 ha per sit over a three-year period (Nelson City Council 1999; Tasman District Council 2000). On the other hand, any indigenous vegetation should not be cleared unless the indigenous vegetation is less than 0.5 ha which is totally surrounded by pasture and other exotic species in the Queenstown Lake District (Queenstown Lake District Council 2003).

\section{The effectiveness of the Resource Manage- ment Act}

The establishment of RMA and the accompanying reforms of administration bodies and local governments did provide the platform to achieve the national goals on resource management: to provide an integrated approach on resource management for reducing conflicts over resource use. The implementation, a decade on from enactment, however, has been highly variable with respect to commitment or desire to embrace the new concepts embodied within the RMA. Some local authorities and planners have made a good attempt to come to terms with the contents and philosophy of the legislation. Most are struggling to grapple with the difficult task of implementing 450 pages of wide-ranging resource management law (Novis 1997).

The difficulty of "effect-based approach" is also pointed out (Dixon \& Montz 1995; Novis 1997; Erickson et al. 2002). The effect-based approach requires an EIA and public hearing. However, the council planners struggle with the appropriate method or criteria to evaluate impacts on natural systems because knowledge is incomplete and nobody is certain on the most adequate method or criteria to adopt. Because of this question, some of the regional or district plans focus on the control of activities, rather than 


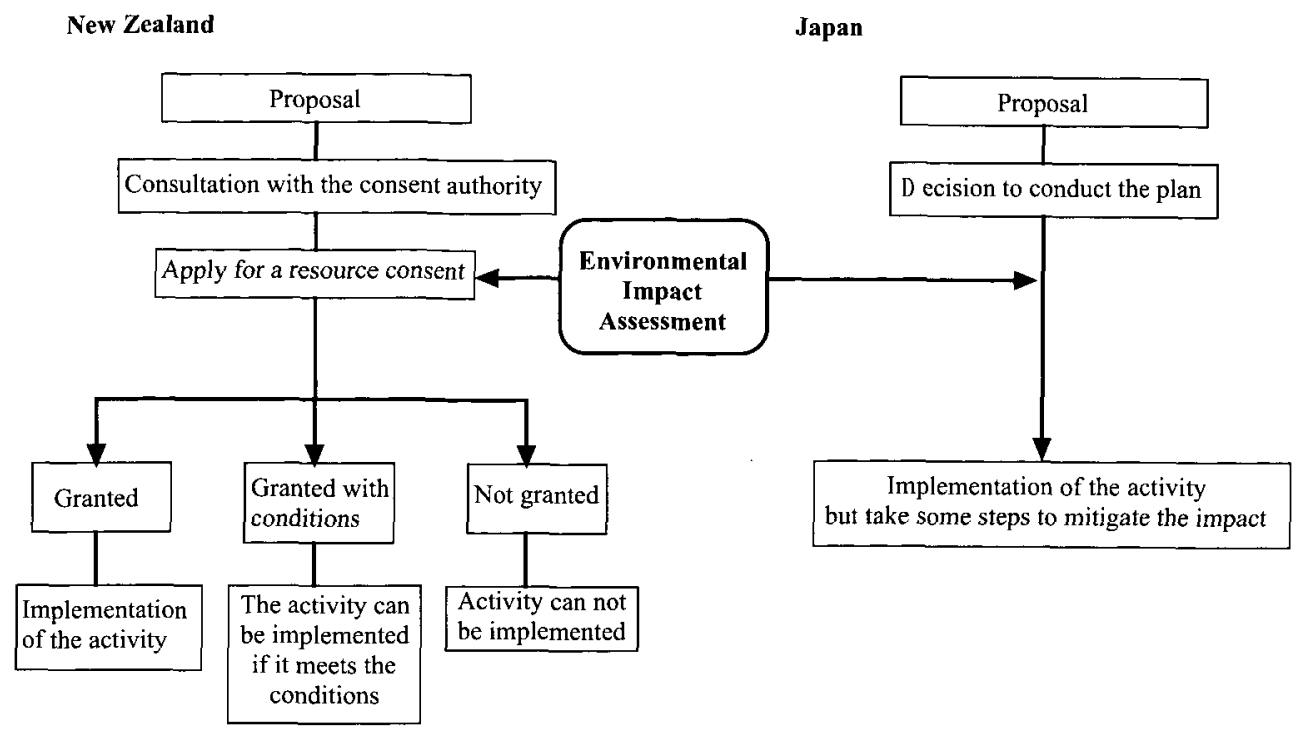

Fig. 3. The stage requires environmental impact assessment in New Zealand and Japan.

the control of adverse effects of activities (Novis 1997). The legal processes to negotiate consents are also designated as a problem because it is tremendous and time taken. When one decides to conduct a certain activity and obtain a consent, the resources required to effectively participate in the process are considerable and often beyond the means of small agencies and individuals (Novis 1997).

The increase in autonomy of the regional council to decide policy within their own regions enabled to reflect their regional situation on resource management. However, it also resulted in startling inconsistencies across some district boundaries with respect to objectives, policies and method of implementation, for instance the difference in treatments of forestry activity. Cooperation between district councils is important to reduce the legal contradiction.

Studies assessing and detecting problems of the RMA with respect to forest management are few. In the case study of the Nelson region, district plans of the Tasman District and the Nelson City showed their effectiveness on conserving indigenous vegetations on the hill country (Nagashima et al. 2003). However, the district plans were found insufficient for managing indigenous forests and shrubs on the lowlands. The indigenous vegetations on lowlands are fragmented by human activities and only a small area is remained. Although those fragmented forests are conserved in a certain extent, plantations were predicted to expand and cover most of the lowlands in the near future (approximately 20-30 years), which may lead the lowland landscape homogenous. This suggests that conservation or enhancement of indigenous species could be more difficult. Establishing corridors that connect the fragmented forests by indigenous vegetations might assist solving the situation and promoting sustainable ecosystem management on the lowlands. Although most of the lowlands are privately owned and there might be a lot of difficulties to reach agreement, a landscape planning showing the area for corridors was recommended to introduce to the district plan. Viles and Rosier (2001) also suggested that majority of agencies responsible for biodiversity conservation generally focus only on the protection of significant patches and the role of corridors or greenways has not been recognized.

\section{Forest Management system in Japan}

Legislations related to forest management and conservation in Japan has been established to achieve specific objective in a relative isolation (Table 3). However, the relationships between legislations are obscure and confusing. For instance, Natural Parks Law that established in 1957 aims to conserve beautiful natural landscape and utilize it for the public. The objective of Nature Conservation Law is to enhance appropriate conservation of natural environment, especially significant indigenous habitats, in an integrated manner. The Nature Conservation Law was established fifteen years later than the Natural Parks Law and it says 
that areas which have already been identified as a National Parks under the Natural Parks Law cannot be designated as a Nature Conservation Area. Most areas with significant indigenous ecosystems have already been appointed as a Natural Parks when the Nature Conservation Law was enacted and consequently, only a little area was identified as a Nature Conservation Area. However, it is said that significant indigenous ecosystem within the Natural Parks should be re-designated to the Nature Conservation Area to conserve the area appropriately (Yamamura 2002).

Administrative bodies that take roles of enforcement are also quite separated (Table 3). The Forestry Agency is responsible for managing forestry and for detecting protection forests. The Ministry of the Environment takes the role to conserve significant indigenous ecosystems and to manage National Parks. Forests distributes in urban areas are managed by the Ministry of Land, Infrastructure and Transport. Natural heritages are under the control of the Agency for Cultural Affairs. The problem of this separation is that the difference of management principle by the administrative bodies. The overlapping area of Nature Conservation Area (under the Nature Conservation Law) managed by Ministry of the Environment and Protection Forests (under the Forest Law) administrated by Forestry Agency might be a good example for this. The Nature Conservation Law allows designating a Protection Forests as a Nature Conservation Area. However, activities such as earth works could be conducted if it gets the permission under the Forest Law but not the Nature Conservation Law (Yamamura 2002), which may reduce the effectiveness of the Nature Conservation Law. The ineffectiveness of urban forest management by the Ministry of Land, Infrastructure and Transport under the City Green Zone Conservation Law is also pointed out because the Ministry has its priority on effective use of land than conserving the ecosystem

(Yamamura 1994). Managing urban forests by the Ministry of the Environment is recommended because the ministry may put more effort to manage the area in ecological basis.

For the purpose of implementing integrated resource management sited in the Agenda 21, Japan established the Basic Environment Plan in 1993 that provides the principle of environmental policy and covers issues of nature conservation, pollution control, and other environmental issues
(Sasaki 1998). In accordance with the provision of the Basic Environment Law, the Basic Environment Plan was formulated. The plan prescribes four long-term objectives; namely, environmentally sound material cycle, harmonious coexistence, participation and international activities. The plan also identifies outlines of the policies, roles of each entity of the society and the use of various policy instruments to achieve the objectives (UN 1997). However, some papers pointed out the obscure relationship between the plan and other environmental laws. Yamamura (2002) indicated that the plan has a consistency with laws administered by the Ministry of Environment but not with other laws managed by other administrative bodies. Although the Forest Law and the Forestry Basic Law were amended to keep harmony with the Basic Environment Plan, Kitao (2003) criticized that the amendment only changed the purpose to the one that attracts the public interests but no concrete solution was provided on achieving sustainable forest management. The amendment put forward the management purpose of water and land conservation, but little were mentioned on how to achieve sustainable forest management, especially in private forests. One of the main problems in forestry is the forest degradation caused by the abandonment of forest management in private forests due to the low profitability. Therefore, how to support those individual forest owners for achieving sustainable forest management is a critical issue.

In addition, it is said that the relationship between the Basic Environment Plan and land use management policies is also indistinct. Land uses in Japan are controlled by the Comprehensive National Development Plan, which determines the use of land, water and other resources, and the proper locations for industries, and the National Land Use Plan, which placed under the Comprehensive National Development Plan and provides the framework of national land use. The Basic Environment Plan is on a par with the Comprehensive National Development Plan, so that no priority is given to the environmental policy on controlling the land use. In addition, the Basic Environment Plan lacks the system to evaluate the land use plans from an environmental aspect and therefore, their relationship is obscure (Nakaguchi 1998) (Fig. 4). Although the Basic Environment Plan prescribes the importance of EIA, and the Environmental Impact Assessment Law was formu- 
Table 3. Environmental laws related to forest management in Japan.

\begin{tabular}{|c|c|c|c|}
\hline & Name of Law & Contents & Administration Body \\
\hline \multirow[t]{6}{*}{$\begin{array}{l}\text { laws which main pur- } \\
\text { pose is conservation }\end{array}$} & Nature Conservation Law & $\begin{array}{l}\text { Designate indigenous natural environment con- } \\
\text { servation area, natural environment conserva- } \\
\text { tion area to enhance appropriate conservation. }\end{array}$ & $\begin{array}{l}\text { Ministry of the Environ- } \\
\text { ment }\end{array}$ \\
\hline & Natural Park Law & $\begin{array}{l}\text { Designate National Park and quasi-national } \\
\text { park to conserve beautiful natural landscape } \\
\text { and to enhance public use. }\end{array}$ & $\begin{array}{l}\text { Ministry of the Environ- } \\
\text { ment }\end{array}$ \\
\hline & City Green Zone Conservation Law & $\begin{array}{l}\text { Designation and protection of green zones and } \\
\text { promoting tree planting in the city area }\end{array}$ & $\begin{array}{l}\text { Ministry of Land, Infra- } \\
\text { structure, and Transport }\end{array}$ \\
\hline & $\begin{array}{l}\text { Law for the Conservation of Green } \\
\text { Belts around the National Capital Region }\end{array}$ & $\begin{array}{l}\text { Specify and conservation of the green area } \\
\text { around the national capital }\end{array}$ & $\begin{array}{l}\text { Ministry of Land, Infra- } \\
\text { structure, and Transport }\end{array}$ \\
\hline & $\begin{array}{l}\text { Law for the Conservation of Endan- } \\
\text { gered Species of Wild Fauna and Flora }\end{array}$ & $\begin{array}{l}\text { Conservation of endangered species of wildlife } \\
\text { flora and fauna }\end{array}$ & $\begin{array}{l}\text { Ministry of the Environ- } \\
\text { ment }\end{array}$ \\
\hline & Wildlife Protection and Hunting Law & Protect wildlife by regulating hunting & $\begin{array}{l}\text { Ministry of the Environ- } \\
\text { ment }\end{array}$ \\
\hline \multirow{4}{*}{$\begin{array}{l}\text { Laws including provi- } \\
\text { sions that may con- } \\
\text { tribute to nature } \\
\text { conservation }\end{array}$} & City Park Law & $\begin{array}{l}\text { Establishment of city parks to enhance envi- } \\
\text { ronment of the city }\end{array}$ & $\begin{array}{l}\text { Ministry of Land, Infra- } \\
\text { structure, and Transport }\end{array}$ \\
\hline & City Planning Law & $\begin{array}{l}\text { Designating scenic zone and urbanization con- } \\
\text { trol area }\end{array}$ & $\begin{array}{l}\text { Ministry of Land, Infra- } \\
\text { structure, and Transport }\end{array}$ \\
\hline & $\begin{array}{l}\text { Law for the Protection of Cultural Prop- } \\
\text { erties }\end{array}$ & $\begin{array}{l}\text { Conservation of historic spots and natural } \\
\text { monuments }\end{array}$ & $\begin{array}{l}\text { Agency for Cultural } \\
\text { Affairs }\end{array}$ \\
\hline & Forest Law & $\begin{array}{l}\text { Designation and protection of forestry area } \\
\text { Designation of protection forests }\end{array}$ & Forestry Agency \\
\hline
\end{tabular}

lated in 1997, the assessment is only implemented for remedying or mitigating the impact by public works and not to evaluate the plan itself (Fig. 3). Hence, the Basic Environment Plan does not have enough power to promote sustainable resource or forest management.

\section{Conclusion}

The dichotomous management system that divided the role of indigenous forest and plantation forest clearly, allowed the indigenous forest to be protected. However, NZ was able to conduct this system because large area of indigenous forest in NZ had already converted to pasture and indigenous forest was only remaining on $23 \%$ of the national land and because plantation forestry had already grown up as a promising industry for exportation. The distribution pattern of the indigenous forests and plantation forests can also be pointed out. Indigenous forests remain on relatively steep slopes, which indicates that plantation forests distribute on relatively gentle slopes. The pressure of forest management rationalization and the conservation movement were another driving force.

On the other hand, forests in Japan occupy more than
$60 \%$ of the land and mostly distribute on steep slopes. It is obvious that even production forests need to be managed from the aspect of land conservation (Minowa 1997b). In addition, the profitability of Japan's production forests is lower than NZ. The quality of production forests should be extremely high in order to be profitable, which is far from the real estate (Iida 1992). Therefore, the dichotomous forest management system itself is not likely to apply for Japan. However, clarifying the role of administration bodies and the legislation related to forests might be possible to introduce. Forest legislations and the administration bodies in Japan are still fragmented as shown in Table 3. It might be possible to integrate or amend some legislation for example Natural Parks Law and Nature Conservation Law by reviewing carefully the statutes. Transforming the responsibility of urban forest management from the Ministry of Land, Infrastructure, and Transport to the Ministry of the Environment might be another point to be discussed.

New Zealand had established an integrated resource management system based on the RMA. The establishment accompanied by the central government reform, local government reform and the integration of environmental legis- 


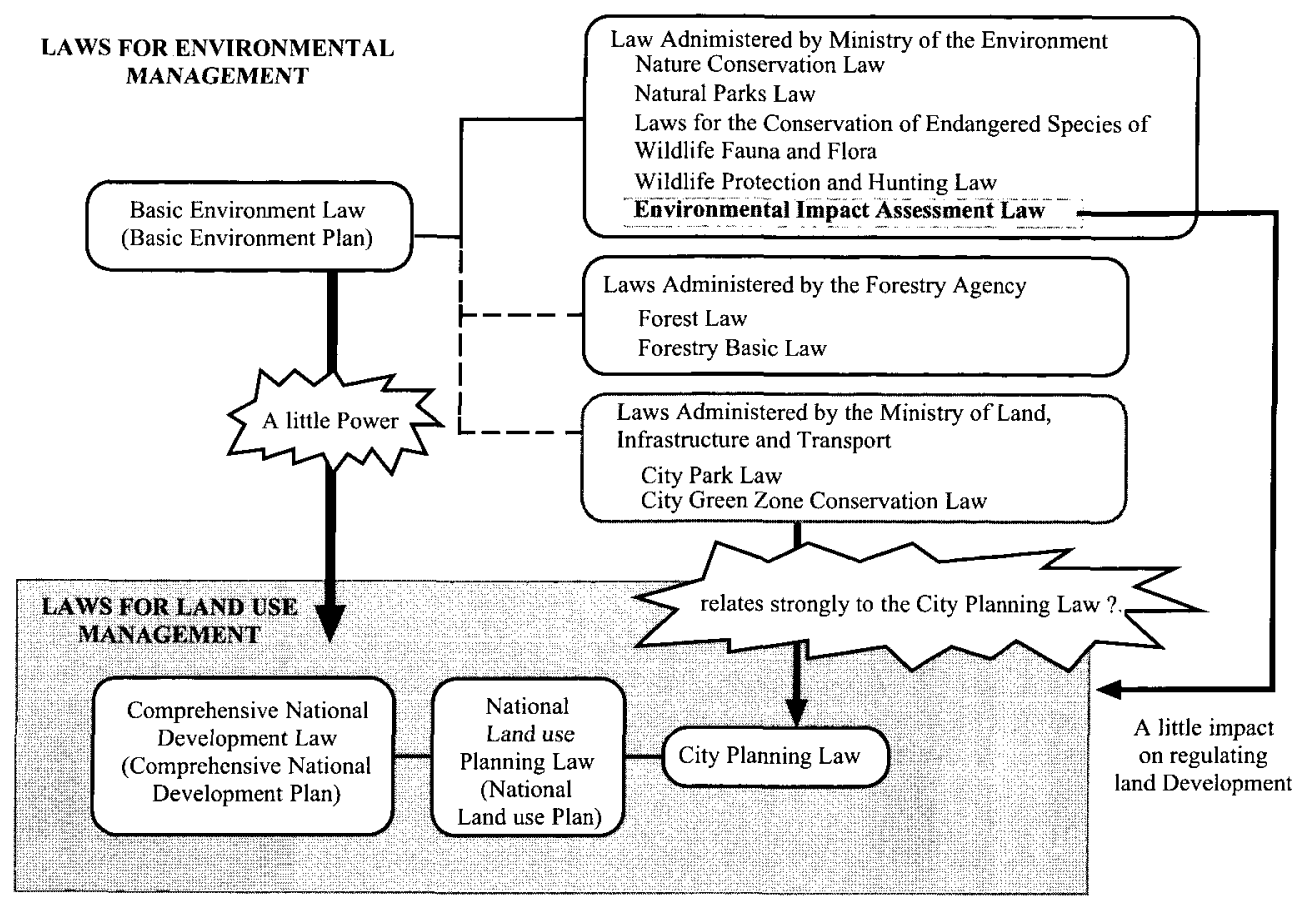

Fig. 4. Relationship of environmental or forest management laws and land use management laws in Japan.

lations. The central government reform integrated the administration responsibilities of land, air and water to the Ministry for the Environment, which enabled to manage natural resources conjunction with the management of land use. The power of land use and resource management was decentralized to the local authorities and the regional boundaries were changed based on natural river catchments in order to promote efficient resource management. Legislations related to environment were amended or repealed to make a clear and consistent legal system based on the RMA.

It is clear that the RMA provided the platform to implement integrated resource management. Although some problems such as the difficulty of evaluating environmental impacts and the time taken legal processes to obtain consents are remaining, the RMA is an advanced comprehensive environmental law that put every effort to minimize contradiction among legislations and conflicts among administration bodies. It is also highly remarkable that the EIA forms a central part of the RMA and it is introduced at the planning stage.

Although Japan established a Basic Environment Plan to promote sustainable land use, its system is far from inte- grated resource management. Its relationship with other environmental laws that managed by administration bodies other than the Ministry of the Environment is obscure. In addition, the Basic Environment Plan lacks a system to control land uses. The Environmental Impact Assessment Law should be the one that evaluates land development activities from an environmental aspect. However, EIA is only implemented after the activity was decided to be conduct. Therefore, it has a little impact on land use control and on achieving sustainable land use. In order to establish an integrated management system to accomplish sustainable resource management, only adding a new law is not enough. Reviewing process of the administration system and legislations might be important as conducted in NZ. In addition, the EIA should be adopted at the planning stage to control land uses from an environmental aspects. 


\section{摘 要}

近年，森林管理と土地利用政策が一体化した包括的な 資源管理システムの構築が世界的な課題となっている. ニュージーランド $(\mathrm{NZ})$ は自然林と人工林の役割を分化 するとともに，資源管理法を策定し，いち早く包括的な 資源管理システムを構築した。本稿では，多くの示唆に 富むNZの資源管理システムの構築過程とその効果・問 題点について概説する。また，我が国の森林管理システ 厶との比較も行う。

NZは自然林を環境保全に人工林を木材生産に, とその 役割を分化させた管理を行っている。このような管理が 可能になったのは，（1）白然林の多くが既に伐採され， 急斜面に残存するのみであること，(2)人工林による林 業が盛んであること，(3)森林管理の効率化と環境保護 活動の圧力の存在, が背景として挙げられる。そのため, 森林の分布状況や林業の現況が大きく異なる我が国では， このような森林管理方針を導入するのは難しいと思われ る。しかし，森林管理に携わる行政機関や関連法規の役 割を明確化させることは有益と思われる。

資源管理法は, 中央省广・地方自治体の改革そして環 境に関する法規の統合という過程を伴って制定された。 資源管理法は各省庁間や各法律間の矛盾や詨立をなくし， 包括的な資源管理を可能にする素地を提供したといえる. 我が国では包括的な資源管理を実践するために，法律を 付け加えることで対処してきたが, NZのように管理省庁 や法律を徹底的に見直し，一貫性のあるシステムを構築 することが必要と思われる。

\section{References}

Allen, R. B., Platt, K.H. \& Coker, R. E. J. (1995a) Understory species composition patterns in a Pinus radiata D. Don plantation on the central North Island Volcanic Plateau, New Zealand. New Zealand Journal of Forestry Science 25: 301-317.

Allen, R. B., Platt, K. H. \& Wiser, S. (1995b) Biodiversity in New Zealand plantations. New Zealand Forestry 39(4): 2629.

Bergin, D. O. \& Kimberley, M. O. (1995) Protective value of regenerating tea tree stands on erosion-prone hill country, East Coast, North Island, New Zealand. New Zealand Journal of Forestry Science 25: 3-19.

Bilek, E. M. (1994) Privatization of state-owned forests: An experiment in New Zealand. Sanrin 1327: 1-10. (in Japanese)

Clout, M. N. (1980) Comparisons of bird populations in exotic plantations and native forest. New Zealand Journal of Ecology 3: 150-160.

Clout, M. N. \& Gaze, P. D. (1984) Effects of plantation forestry on birds in New Zealand. Journal of Applied Ecology 21: 795-815.

Dickinson, K. J. M., Mark, A. F., Barratt, B. I. P. \& Patrick, B. H. (1998) Rapid ecological survey, inventory and implementation: A case study from Waikaia Ecological Region, New Zealand. Journal of the Royal Society of New Zealand $28(1)$ : 83-156.

Dixon, J. \& Montz, B. E. (1995) From concept to practice: implementing cumulative impact assessment in New Zealand. Environmental Management 19(3): 445-456.

Dyck, W. J. (1997) Biodiversity in New Zealand plantation forestry: An industry perspective. New Zealand Forestry $42(3)$ : 6-8.

Erickson, N., Crawford, J., Berke, P. \& Dixon, J. (2002) Resource Management, Plan Quality, and Governance. The International Global Change Institute, University of Waikato, Hamilton.

FAO. (1996) For the formulation, implementation and revision of national forestry programs. FAO, Rome.

Fletcher, J. R. (1984) Pastoral land: horticulture and forestry as competing land uses. New Zealand Agricultural Science 183: 164-167.

Gibb, J. A. (1961) Ecology of the birds in Kaingaroa forest. Proceeding of the New Zealand Ecological Society 8: 29-38.

Hallett, J. (1991) The Native Forests of New Zealand. GP publications Ltd., Wellington.

Hicks, D. L. (1991) Erosion under pasture, pine plantations, scrub and indigenous forest: a comparison from Cyclone Bola New Zealand Forestry 36(3): 21-22.

Hiramatu, K. (1997). Law of environmental assessment in New Zealand. The Aoyama law review 38(3,4): 1-16. (in Japanese)

Iida, S. (1992) National Forests: the past, present and future. Tsukuba Publication Co. Ltd., Tokyo. (in Japanese)

Kakizawa, H. (2000) Ecosystem Management. Tsukiji-shokan co., Tokyo. (in Japanese)

Kakizawa, H. \& Nozaki, N. (2001) Current state of resource management system in New Zealand: Neo-liberalism and resource management. Journal of Japanese Forestry Society 83(1): 5-13. (in Japanese)

Kirkland, A. \& Berg, P. (1997) A Century of State-honed Enterprise: 100 Years of State Plantation Forestry in New Zealand. Profile Books, Masterton.

Kitao, K. (2003) The state of the new Basic Law on Forest and Forestry, which is sandwiched between the Forestry Policy as in the past and the new Environmental Conservation Policy. Journal of Forest Economics 49(1): 13-22.

Konohira, Y. (1989) Mono-cultural and industrialized forestry in New Zealand. Forest Economy, August: 1-9. (in Japanese)

Le Heron, R. B. \& Roche, M. M. (1985) Expanding exotic forestry and the extension of a competing use for rural land in New Zealand. Journal of Rural Studies 1 (3): 211-229.

MacLaren, J. P. (1996) Environmental Effects of Planted Forests in New Zealand. FRI Bulletin no. 198. New Zealand Forest Research Institute, Rotorua.

Marden, M. \& Rowan, D. (1993) Protective value of vegetation on tertiary terrain before and during cyclone bola, east coast, 
North Island, New Zealand. New Zealand Journal of Forestry Science 23(3): 255-263.

Mark, A. F., Dickinson, K. J. M., Patrick, B. H., Barratt, B. I. P., Loh, G., McSweeney, G. D., Meurk, C. D., Timmins, S. M., Simpson, N. C., \& Wilson, J. B. (1989) An ecological survey of the central part of the Eyre Ecological District, northern Southland, New Zealand. Journal of Royal Society New Zealand 19: 349-384.

Masui, K. (1996) Agricultural land-use in New Zealand: changing its land-use dramatically toward the 21st century. Agriculture administration Research Bulletin 480: 2-8. (in Japanese)

Milne, C. D. A. (1992) Handbook of Environmental Law. Royal Forest and Bird Protection Society of New Zealand, Wellington.

Minowa, M. (1997a) Privatization of state-owned forests in New Zealand. Weekly Journal of Agriculture and Forestry 1644: 6-7. (in Japanese)

Minowa, M. (1997b) Privatization of state-owned forests in New Zealand. Journal of Forest Economy Research 43(1): 110-114. (in Japanese)

Nagashima, K., Sands, R., Whyte, A. G. D., Bilek, E. M. \& Nakagoshi, N. (2002) Regional landscape change as a consequence of plantation forestry expansion: an example in the Nelson region, New Zealand. Forest Ecology and Management, 163: 245-261.

Nagashima, K., Sands, R., Whyte, A. G. D., Bilek, E. M. \& Nakagoshi, N. (2003) Plantation expansion possibility and its influence on land-use pattern in the Nelson Region, New Zealand. Forest Ecology and Management, in press.

Nakaguchi, T. (1998) Evaluation of future land use goals by natural environmental indices: A case study of Miyagi Prefecture. Papers of the Annual Conference on City Planning 33: 817-822. (in Japanese)

Nelson City Council. (1999) Nelson Resource Management Plan. Nelson City Council, Nelson.

New Zealand Ministry for the Environment. (1991) Managing Our Future. New Zealand Ministry for the Environment, Wellington.

New Zealand Ministry of Agriculture and Forestry. (1998) New Zealand Forestry Statistics: 1997. New Zealand Ministry of Agriculture and Forestry, Wellington.

New Zealand Ministry of Agriculture and Forestry. (2002) A National Exotic Forest Description 2001. New Zealand Ministry of Agriculture and Forestry, Wellington.

New Zealand Ministry of Forestry. (1995) Small Forest Management: the resource management act. New Zealand Ministry of Forestry, Wellington.
Novis, J. (1997) The resource management act: six years on. New Zealand Journal of Forestry 42(1): 3-6.

Ogden, J., Braggins, K., \& Anderson, A. (1997) Plant species richness under Pinus radiata stands on the Central North Island Volcanic Plateau, New Zealand. New Zealand Journal of Ecology 21: 17-29.

Queenstown Lakes District Council. (2002) Strategy Committee for Meeting of 10 September 2002: Report For Agenda Item 3. Queenstown Lakes District Council, Queenstown.

Queenstown Lakes District Council. (2003) Strategy Committee for Meeting of 8 April 2003: Report For Agenda Item 4. Queenstown Lakes District Council, Queenstown.

Sasaki, S. (1998) Establishment of the Basic Environment Plan and its influence. Journal of Land 31(374): 31-42. (in Japanese)

Spellerberg, I. F. \& Sawyer, W. D. (1995) Multiple-use, biological diversity and standards. New Zealand Forestry 39(4): $21-25$.

Sutton, W. R. J. (1995) Plantation forests protect our biodiversity. New Zealand Forestry $40(3): 2-5$.

Tasman District Council. (2000) Tasman Resource Management Plan. Tasman District Council, Richmond.

Taylor, R., Smith, I., Cochrane, P., Stephenson, B. \& Gibbs, N. (1997) The State of New Zealand's Environment 1997. The New Zealand Ministry for the Environment and GP publications, Wellington.

UN. (1992) Agenda 21. UN, New York.

UN. (1997) National Implementation of Agenda 21: Japan. UN, New York.

UN. (2000) Commission on Sustainable Development Eight session: Integrated Planning and Management of Land Resources, Report of the Secretary-General. UN, New York.

UN. (2001) Commission on Sustainable Development acting as the preparatory committee for the World Summit on Sustainable Development: Agriculture, land and desertification, Report of the Secretary-General. UN, New York.

Viles, R. L. \& Rosier, D. J. (2001) How to use roads in the creation of greenways: case study in three New Zealand landscapes. Landscape and Urban Planning 55: 15-27.

Williams, D. A. R. (1997) Environmental and Resource Management Law in New Zealand. Butterworths, Wellington.

Yamamura, T. (1994) The Low and Strategy for Nature Conservation: Second Edition. Yuhikaku Publishing Co., Ltd., Tokyo. (in Japanese)

Yamamura, T. (2002) Introduction to the Environmental Law: Its Effectiveness and Problems. Syowa-do Co. Ltd., Kyoto. (in Japanese) 